\title{
Liver toxicity assessments in rats following sub-chronic oral exposure to copper nanoparticles
}

\author{
Huaqiao Tang, Min Xu, Jie Luo, Ling Zhao, Gang Ye, Fei Shi, Cheng Lv, Helin Chen, Yanyan Wang and Yinglun Li
}

\begin{abstract}
Background: The widespread use of nano-copper as a feed additive in the absence of toxicological studies has potential risks to humans and animals. Toxicity studies on nano-copper in animals usually exposure from the respiratory tract, however, it is necessary to study the oral exposure toxicity of nano-copper to understand its risks as a feed additive.

Results: Currently the hepatotoxicity and mechanism of nano-copper after sub-choronic oral exposure at equivalent doses of 50, 100, and $200 \mathrm{mg} / \mathrm{kg} /$ day were evaluated in rats; micro-copper and Cu ions were used as controls. Nanocopper $(200 \mathrm{mg} / \mathrm{kg}$ ) increased serum alanine aminotransferase and aspartate aminotransferase significantly, further promoting hepatic oxidative stress, inflammation, and corresponding histopathological changes, and exhibited significant dose-dependent changes. Nano-copper also decreased the level of nuclear receptors, resulting in significant reductions in mRNA, protein, and activity of hepatic CYP450 enzymes. The molecular mechanisms responsible for these toxic effects involved the signaling pathway of NF-KB, MAPK, and STAT5.
\end{abstract}

Conclusions: Nano-copper caused strong hepatic toxicity by inducing oxidative stress and inflammation. The decreased drug metabolism enzymes lead to nano-copper-drug interaction that provoked the concerns on animalderived food safety.

Keywords: Nano-copper, CYP450 enzymes, Inflammation, Oxidative stress, Signaling pathway

\section{Introduction}

With the increasing resistance of bacteria to antibiotics, there have been increased concerns about the widespread use of veterinary antimicrobials for antibacterial and growth promotion [1]. The growing demand for meat products is an important reason to promote the use of antibiotics in farms; however, a dilemma persists in the selection and use of antibiotics to deal with animal infection [2]. Large-scale investigations have found that many resistant plasmids can drift between different bacteria, which increases the challenge of zoonosis for public health [3]. Therefore, we are in urgent need of new antibacterial substances that can be used to treat animal

\footnotetext{
*Correspondence: liyinglun02@163.com

Department of Pharmacy, College of Veterinary Medicine, Sichuan

Agricultural University, 211 Huimin Road, Wenjiang District,

Chengdu 611130, China
}

diseases with lower risks to animals and humans. Currently, due to the antibacterial and growth promoting effects on animals, metal nano-preparation has become a good choice as a feed additive $[4,5]$. People have been eager to use nano-copper as a feed additive $[6,7]$. Therefore, we think it is a suitable time to evaluate whether nano-copper is safe for animal with large-dose and longterm oral exposure, and the further impacts on humans will be discussed.

Copper $(\mathrm{Cu})$ is one of the essential nutrients to maintain normal physiological and biochemical functions in animals and humans [8]. Copper nanoparticles (nanocopper) are used as antibacterial and antifouling agents in all kinds of industrial products [9]. The excessive application of nano-copper increased exposure to humans, animals, and the environment. We need more toxicity data to ensure the safe use of nano-copper in future, especially 
the application as the drug sources of antibacterial, antitumor, and feed additive [10-12].

Since the efficacy and toxicity of nano-copper are directly related to their particle size, we have evaluated the $\mathrm{LD}_{50}$ values of $\mathrm{Cu}$ ions, $30 \mathrm{~nm}, 50 \mathrm{~nm}, 80 \mathrm{~nm}$, and $1 \mu \mathrm{m}$ copper particles were $359.6,1022,1750,2075$, and $>5000 \mathrm{mg} / \mathrm{kg}$, respectively [13]. Nanoparticles can break through a variety of biological barriers and widely disseminate and accumulate in multiple organs, especially the liver and kidneys, when exposed to respiratory and oral routes $[14,15]$. When nano-copper entered into the blood circulation system, it mediated oxidative responses and activated a series of pathological events such as genotoxicity, inflammation, fibrosis, and carcinogenesis [16]. The liver, kidney, and spleen are the main toxic target organs of nano-copper particles [17]. The increased oxidative stress will activate related regulation pathways resulting in increased expression of proinflammatory cytokines $[18,19]$. Therefore, the toxic effects of nanocopper on the liver may be more extensive than currently evaluated, and more toxicity studies need to be done to ensure their rational use.

The liver plays a crucial role in determining the toxicity of drugs due to its key role in the metabolism, transport, and clearance of foreign substances. Most of the xenobiotic substances metabolized in liver by cytochrome $\mathrm{P} 450$ enzymes (CYP450), and three CYP families, CYP1A, 2A, and $3 \mathrm{~A}$, which account for $77 \%$ of the reported xenobiotic biotransformation [20]. However, the metabolism function of liver can be affected by many factors, and the inhibition and induction of drug-metabolizing enzymes are important causes of drug-drug interactions [21-23]. Inflammation and oxidative stress have been shown to be one of the potential factors for the inhibition of CYP450 [24]. Therefore, it is important to study whether nanocopper in feed causes liver damage in animals, especially the impacts on drug metabolism enzymes.

In this work, we discussed the hepatoxicity and mechanism of nano-copper in rats after sub-chronic oral exposure, especially on hepatic CYP450 enzymes. The information may help us to predict the risks of nano-copper on human and animals when it's used in medications or animal feed.

\section{Materials and methods}

\section{Test materials and their characterization}

The tested copper particles were compared with copper ions $\left(\mathrm{CuCl}_{2} \cdot 2 \mathrm{H}_{2} \mathrm{O}\right)$, which were manufactured by Aladdin Industrial Corporation. The size of copper particles was characterized with a scanning electron microscope (Phenom ProX, Nani Scientific Instruments LTD, Shanghai, China).
The nano- and micro-coppers were added to $1 \%$ HPMC to obtain a stock suspension of $10 \mathrm{~g} / \mathrm{L}$, which was shaken and sonicated in ice bath. The distribution of particle sizes in this suspension was characterized with dynamic light scattering performed with a Zeta sizer Nano ZS (Malvern Instruments, Malvern, UK) immediately after sonication.

\section{Experiment design}

The protocols for animal studies were reviewed and approved by the Animal Ethical Committee of Sichuan Agricultural University (\#:20171120). 63 Specific pathogen-free (SPF) male Sprague-Dawley rats (aged 8 weeks; 100-120 g) were bought from Chengdu Dossy Biological Technology Co., Ltd (Chengdu, China) and housed under SPF conditions. The room temperature was kept between 20 and $24{ }^{\circ} \mathrm{C}$, and humidity ranged from 40 to $70 \%$ with a $12 \mathrm{~h}$ light-12 $\mathrm{h}$ dark cycle, food and water were available ad libitum. Rats were divided as one control group and 6 test groups $(n=9)$. In addition to the control group (1\% hydroxypropyl methylcellulose solution, HPMC), the experimental groups were treated with $1 \mu \mathrm{m}$ copper (200 mg/kg), $\mathrm{CuCl}_{2} \cdot 2 \mathrm{H}_{2} \mathrm{O}(100 \mathrm{mg} / \mathrm{kg})$, and nano-copper $50 \mathrm{mg} / \mathrm{kg}$, nano-copper $100 \mathrm{mg} / \mathrm{kg}$, and nano-copper $200 \mathrm{mg} / \mathrm{kg} .80 \mathrm{~nm}$ copper was usually used as a feed additive and these dosages were based on the $\mathrm{LD}_{50}$ and the amount was added to the animal feed (50-500 $\mathrm{mg} / \mathrm{kg}$ diet in China). Since $\mathrm{CuCl}_{2} \cdot 2 \mathrm{H}_{2} \mathrm{O}$ was the main copper source used as custom feed additive, it was chosen as one of the controls. The micro-copper was another control for comparing the sizes-cytotoxicity relationship.

All copper particles were dispersed in a 1\% HPMC solution before use. The rats were exposure to different coppers for 28 days by continuous gavage. All rats were anesthetized at the end of the treatment, and blood samples were collected by cardiac puncture. After collecting blood, rats were euthanized, and the liver tissues were quickly removed and divided into four portions as the different lobes. Left lateral hepatic lobes were used to isolate liver microsomes by differential centrifugation [25], the left middle lobes were fixed in paraformaldehyde for histopathological analysis, the middle lobes were used to detect inflammatory factors, oxidative stress, and the right lobes were used for gene and protein expression detection. All liver tissues were stored in liquid nitrogen until analysis.

\section{Measurements of cytokines and oxidative stress}

After liver tissues were fully homogenized, the levels of interleukin (IL)-1 $\beta$, IL-2, IL-4, IL-6, tumor necrosis factor-alpha (TNF- $\alpha$ ), cyclooxygenase-2 (COX-2), monocyte chemotactic protein-1 (MCP-1), and macrophage inflammatory protein (MIP)- $1 \alpha$ were determined by 
MAGPIX (R\&D Systems) in accordance with the manufacturer's instructions.

The levels of total antioxidant capacity (T-AOC: 2,2'-azino-bis(3-ethylbenzthiazoline-6-sulfonic acid(ABTS) oxidation), catalase (CAT: ammonium molybdate colorimetry), superoxide dismutase [SOD: (2-(2-methoxy-4-nitrophenyl)-3-(4-nitrophenyl)-5-(2,4disulfophenyl)-2H-tetrazole monosodium salt (WST8) catalytic reaction], glutathione peroxidase (GSH-Px: hydroperoxide catalytic reduction reaction), nitric oxide synthase (iNOS: ELISA kit), and the contents of malondialdehyde [MDA: thiobarbituric acid (TBA) color reaction] and nitric oxide (NO: griess reagent detection) were evaluated in accordance with the manufacturer's instructions for the appropriate kits (Nanjing Jiancheng Bioengineering Institute, Nanjing, China).

\section{Gene expression analyze}

RNA extractions and analysis of liver tissue gene expression were performed as described, with minor changes [26]. The quantity of extracted RNA was assessed with UV spectroscopy (NanoDrop 2000 UV-Vis Spectrophotometer, Thermo Scientific; Waltham, MA, USA). The following target genes were analyzed for their expression: constitutive androstane receptor $(C A R)$, pregnane $X$ receptor $(P X R)$, aryl hydrocarbon receptor $(A H R)$, CYP450 1A2, 2C11, 2D6, 2E1, and 3A2. GAPDH was used as the housekeeping gene for data normalization (the PCR primers were shown in Table 1.).

\section{Measurement of protein expression}

The protein expression of CYP450 1A2, 2C11, 2D6, 2E1, 3A2, CAR, PXR, and AhR in the liver microsomes of rats were estimated with Western immunoblot analyses $[27,28] .30 \mu \mathrm{g}$ of microsomal proteins were separated by SDS polyacrylamide gel electrophoresis (Bio-Rad Laboratories, Inc.). After incubation with a primary and secondary antibody, the protein bands were visualized with enhanced chemiluminescence, and intensity of the bands was quantified with ImageJ software.

\section{Measurements of CYP450 1A2, 2C11, 2D6, 2E1, and 3A2 activity}

The activities of CYP450 1A2, 2C11, 2D6, 2E1, and 3A2 were assessed [29-31]. Five specific probe substrates were incubated with liver microsomes. The concentrations of probe substrates were monitored by high performance liquid chromatography (HPLC). The decreasing amount of specific probe drugs were used to show the activity of microsomal enzymes (Fig. 1). The regression equations and lower limit of quantitation concentrations for the analytes are shown in Table 2.
Table 1 PCR primers used for analysis of gene expression

\begin{tabular}{lll}
\hline Target & Sequences of primers (5' to $\mathbf{3}^{\prime}$ ) & Base number \\
\hline CYP450 1A2 F & GGTGGAATCGGTGGCTAAT & 19 \\
CYP450 1A2 R & AGTCCTTGCTGCTCTTCACG & 20 \\
CYP450 2C11 F & AATCCGCAGTCTGAGTTTACCC & 22 \\
CYP450 2C11 R & GGTTTCTGCCAATTACACGTTCT & 23 \\
CYP450 2D6 F & AGCTTCAACACCGCTATGGT & 20 \\
CYP450 2D6 R & CAGCAGTGTCCTCTCCATGA & 20 \\
CYP450 2E1 F & CCTTTCCCTCTTCCCATCC & 19 \\
CYP450 2E1 R & AACCTCCGCACATCCTTCC & 19 \\
CYP450 3A1 F & TGCCATCACGGACACAGA & 18 \\
CYP450 3A1 R & ATCTCTTCCACTCCTCATCCTTAG & 24 \\
PXRR & TGATGACGCCCTTGAACATG & 20 \\
CARF & CCACGGGCTATCATTTCCAT & 20 \\
CARR & CCCAGCAAACGGACAGATG & 19 \\
AHRF & TGGACAAACTCTCCGTTCTAAGG & 23 \\
AHR R & GATTTTAATGCAACATCAAAGAAGCT & 26 \\
GAPDH F & GATGGTGAAGGTCGGTGTG & 19 \\
GAPDHR & ATGAAGGGGTCGTTGATGG & 19 \\
\hline
\end{tabular}

\section{Luminex analyze for key signal pathway proteins}

Liver tissue homogenate was prepared with lysate and a protease inhibitor mixed solution at the ratio of $1: 4$ and lysed on ice for $15 \mathrm{~min}$ then centrifuged at $16000 \mathrm{~g}$ at $4{ }^{\circ} \mathrm{C}$ for $15 \mathrm{~min}$. Concentrations of signal pathway proteins were measured with a multiplexed particle-based flow cytometric assay [32, 33]. Luminex technology was used according to the manufacturer's instructions to measure protein and phosphoproteins of CERB, NF-kB, P38, ERK1/2, Akt, p70s6k, STAT3, and STAT5 in rat livers (R\&D Systems).

\section{Statistical analysis}

All statistical results are expressed as the mean \pm standard deviation $(n=9)$, and all experimental groups were compared with the control group. Differences between mean values were analyzed with a one-way ANOVA, and values with superscripts are significantly different $(p<0.05$ or 0.01$)$ in the results.

\section{Results}

Physicochemical characterization of copper nanoparticles

The results of dynamic light scattering analysis (Fig. 2) showed that the spherical copper particles had mean sizes of $82.5 \pm 33.4 \mathrm{~nm}(80 \mathrm{~nm})$ and $987.4 \pm 436.7(1 \mu \mathrm{m})$. The polydispersity index (PDI) of nano- and micro- copper were 0.14 and 0.20 , respectively, according to the laser particle size analyzer test. The size and shape of the copper particles were consistent with the data provided by the manufacturer. 


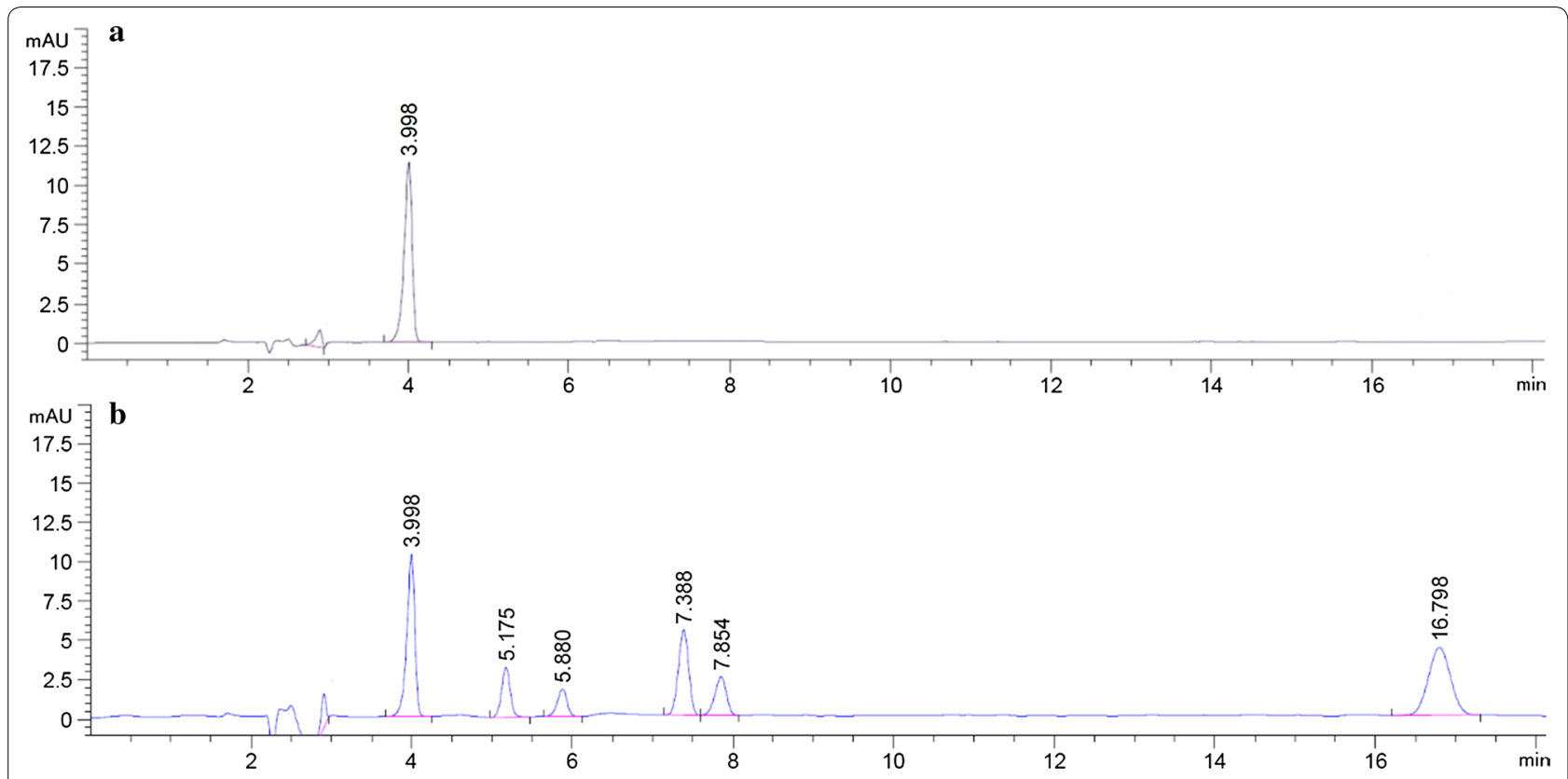

Fig. 1 Chromatograms of five cocktail probe drugs and tinidazole (IS) in the incubation system. a IS in blank sample; b sample spiked with five cocktail probe drugs and IS

Table 2 Regression equation, linear range, and lower limit of quantitation concentrations (LLOQ) for the probe substrates used in incubations

\begin{tabular}{|c|c|c|c|c|}
\hline Analytes & Regression equation & $\begin{array}{l}\text { Correlation coefficient } \\
\left(R^{2}\right)\end{array}$ & Linear range $(\mathrm{ng} / \mathrm{mL})$ & LLOQ (ng/mL) \\
\hline Phenacetin & $y=166.90 x+1.3728$ & 0.9995 & $200-1400$ & 50 \\
\hline Tolbutamide & $y=176.97 x+0.6415$ & 0.9996 & $200-1400$ & 50 \\
\hline Dextromethorphan & $y=128.91 x+1.3531$ & 0.9999 & $200-1400$ & 50 \\
\hline Chlorzoxazone & $y=110.85 x+4.8935$ & 0.9999 & $200-1400$ & 50 \\
\hline Testosterone & $y=212.16 x+49.721$ & 0.9994 & $800-11,200$ & 100 \\
\hline
\end{tabular}

\section{Blood chemistry analyses}

The serum biochemistry results of nano-copper, microcopper, and $\mathrm{Cu}$ ions-treated rats are presented in Table 3. In the $1 \mu \mathrm{m}$ copper-treated rats, the serum concentrations of aspartate aminotransferase (AST), alkaline phosphatase (ALP), albumin/globulin (A/G), and creatine kinase (CK) increased significantly, while globulin (GLB), total protein (TP), and creatinine (CREA) decreased significantly. In the $\mathrm{Cu}$ ions-treated rats, the serum levels of ALP, A/G, and triglyceride (TG) increased significantly, while GLB and TP decreased significantly. In the $200 \mathrm{mg} /$ $\mathrm{kg}$ nano-copper-treated rats, the serum levels of AST increased significantly. The level of serum ALP increased significantly only in the $200 \mathrm{mg} / \mathrm{kg}$ group. In the nanocopper-treated rats, the serum level of ALB, GLB, TP, UREA, and CREA decreased significantly, while the level of A/G increased significantly. The serum level of total cholesterol (TC) decreased significantly in $200 \mathrm{mg} /$ $\mathrm{kg}$-treated rats, while the level of CK decreased in the $100 \mathrm{mg} / \mathrm{kg}$ - and $200 \mathrm{mg} / \mathrm{kg}$-treated rats. The serum level of TG increased significantly in the $100 \mathrm{mg} / \mathrm{kg}$-treated rats. Nano-copper caused strong liver injury and dysfunction by increasing the release of transaminase and decreasing the protein synthesis.

\section{Histopathology}

Histopathological results are illustrated in Fig. 3. The obvious liver sinus congestion can be found in $\mathrm{Cu}$ ionstreated rats. In the micro- and nano-copper-treated rats, the main changes were small vacuoles in hepatocytes and some inflammation infiltration, meanwhile obvious liver structural disorder and hepatocyte swelling were found in $200 \mathrm{mg} / \mathrm{kg}$ nano-copper-treated rats. Liver cells vacuolar degeneration and the appearance of inflammatory cells were the main pathological manifestations of liver damage caused by nano-copper. The pathological 

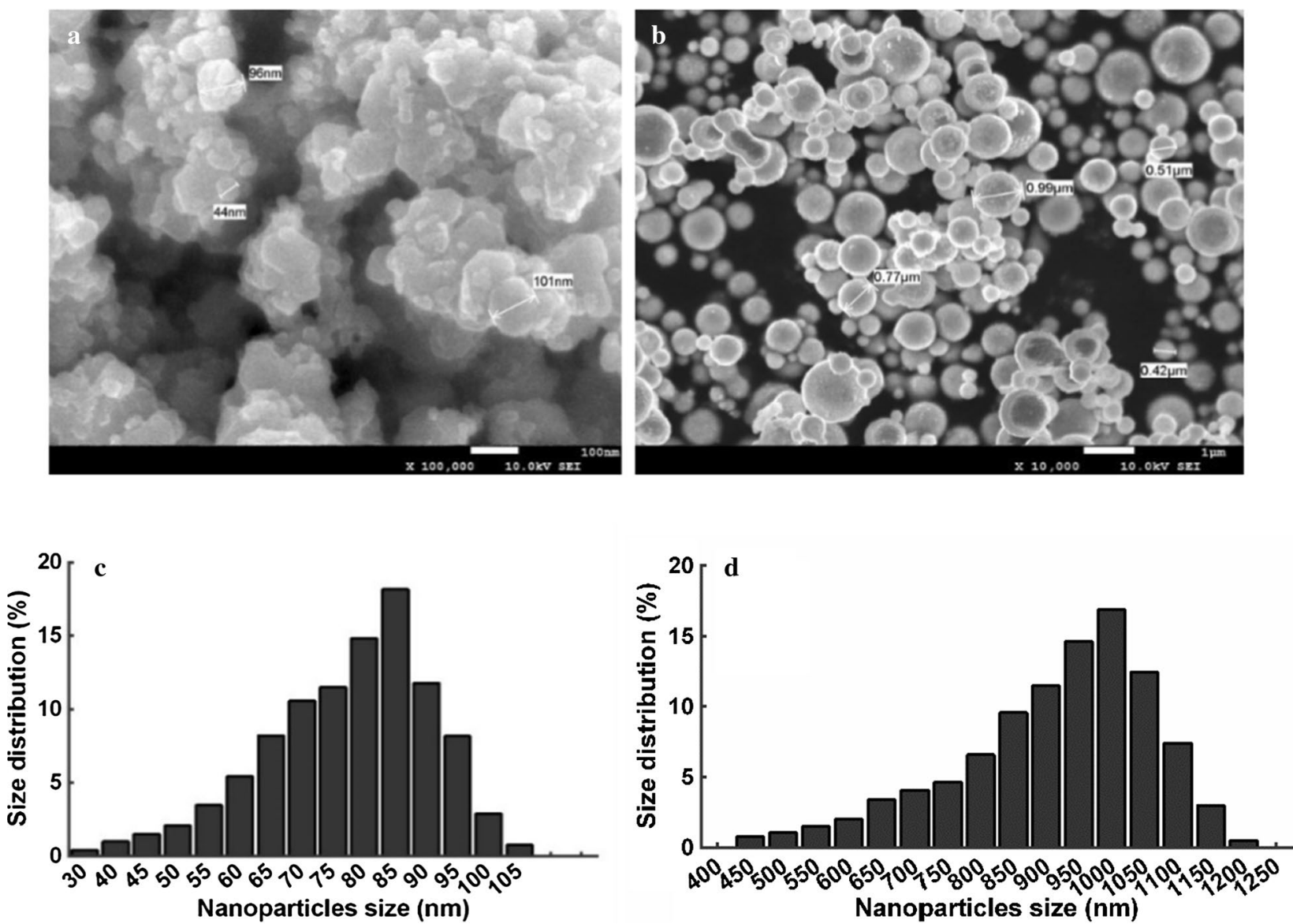

Fig. 2 Characterization of the Cu particles by scanning electron microscopy (a, b), and nanoparticle sizes distributions (c, d)

Table 3 The results of blood biochemical indexes of rats treated with coppers

\begin{tabular}{llllllll}
\hline & ALT & AST & AST/ALT & ALP & ALB & GLB & A/G \\
\hline Control & $61.40 \pm 8.0$ & $166.57 \pm 17.73$ & $2.96 \pm 0.51$ & $204.39 \pm 33.39$ & $34.47 \pm 2.26$ & $30.77 \pm 3.88$ & $1.14 \pm 0.17$ \\
Micro-copper & $63.14 \pm 4.14$ & $221.41 \pm 14.62^{* *}$ & $3.63 \pm 0.58$ & $232.78 \pm 47.38^{*}$ & $33.94 \pm 1.14$ & $25.25 \pm 6.00^{* *}$ & $1.40 \pm 0.26^{* *}$ \\
CuCl$_{2} \cdot 2 \mathrm{H}_{2} \mathrm{O}$ & $65.17 \pm 6.64$ & $174.03 \pm 13.63$ & $2.69 \pm 0.29$ & $251.79 \pm 34.34^{*}$ & $34.61 \pm 1.19$ & $21.74 \pm 3.41^{* *}$ & $1.63 \pm 0.26^{* *}$ \\
Nano-copper $50 \mathrm{mg} / \mathrm{kg}$ & $55.18 \pm 2.44$ & $161.48 \pm 22.80$ & $3.09 \pm 0.93$ & $204.34 \pm 9.04$ & $32.96 \pm 2.19^{*}$ & $23.31 \pm 2.94^{* *}$ & $1.43 \pm 0.12^{* *}$ \\
Nano-copper $100 \mathrm{mg} / \mathrm{kg}$ & $59.50 \pm 4.90$ & $173.76 \pm 17.08$ & $2.92 \pm 0.42$ & $209.12 \pm 12.35$ & $32.34 \pm 2.08^{*}$ & $23.11 \pm 3.21^{* *}$ & $1.42 \pm 0.15^{* *}$ \\
Nano-copper $200 \mathrm{mg} / \mathrm{kg}$ & $61.11 \pm 7.81$ & $220.60 \pm 23.29^{* *}$ & $3.61 \pm 0.37$ & $237.06 \pm 9.36^{*}$ & $31.48 \pm 1.12^{* *}$ & $23.11 \pm 2.25^{* *}$ & $1.38 \pm 0.15^{* *}$ \\
\hline & TC & CK & GLU & TP & UREA & CREA & TG \\
\hline Control & $1.70 \pm 0.43$ & $1076.47 \pm 351.89$ & $10.43 \pm 3.69$ & $65.23 \pm 3.19$ & $8.37 \pm 1.14$ & $26.43 \pm 5.22$ & $0.42 \pm 0.14$ \\
Micro-copper & $1.67 \pm 0.31$ & $1442.84 \pm 493.35^{*}$ & $11.08 \pm 1.21$ & $55.94 \pm 1.70^{* *}$ & $9.47 \pm 2.51$ & $16.41 \pm 6.39^{* *}$ & $0.61 \pm 0.22$ \\
CuCl 2 -2H ${ }_{2} \mathrm{O}$ & $1.97 \pm 0.29$ & $936.51 \pm 193.07$ & $11.11 \pm 2.60$ & $56.36 \pm 3.86^{* *}$ & $6.35 \pm 1.11^{*}$ & $15.52 \pm 4.01^{* *}$ & $0.80 \pm 0.21^{* *}$ \\
Nano-copper $50 \mathrm{mg} / \mathrm{kg}$ & $1.50 \pm 0.35$ & $908.97 \pm 459.04$ & $12.06 \pm 1.54$ & $56.27 \pm 4.76^{* *}$ & $5.07 \pm 1.76^{* *}$ & $15.47 \pm 2.19^{* *}$ & $0.62 \pm 0.13^{*}$ \\
Nano-copper $100 \mathrm{mg} / \mathrm{kg}$ & $1.54 \pm 0.36$ & $510.5 \pm 236.76^{* *}$ & $10.83 \pm 2.26$ & $55.46 \pm 4.88^{* *}$ & $4.65 \pm 1.16^{* *}$ & $16.31 \pm 6.93^{* *}$ & $0.72 \pm 0.30^{* *}$ \\
Nano-copper $200 \mathrm{mg} / \mathrm{kg}$ & $1.34 \pm 0.27^{*}$ & $386.33 \pm 204.55^{* *}$ & $10.05 \pm 1.26$ & $54.59 \pm 1.99^{* *}$ & $5.12 \pm 2.11^{* *}$ & $21.79 \pm 4.39^{*}$ & $0.60 \pm 0.27$ \\
\hline
\end{tabular}

ALT alanine aminotransferase, $A S T$ aspartate aminotransferase, $A L P$ alkaline phosphatase, $A / G$ albumin/globulin, $C K$ creatine kinase, GLB globulin, $T P$ total protein, CREA creatinine, $T G$ triglyceride, $A L B$ albumin, $T C$ cholesterol

${ }^{*} p<0.05 ;{ }^{* *} p<0.01$ 

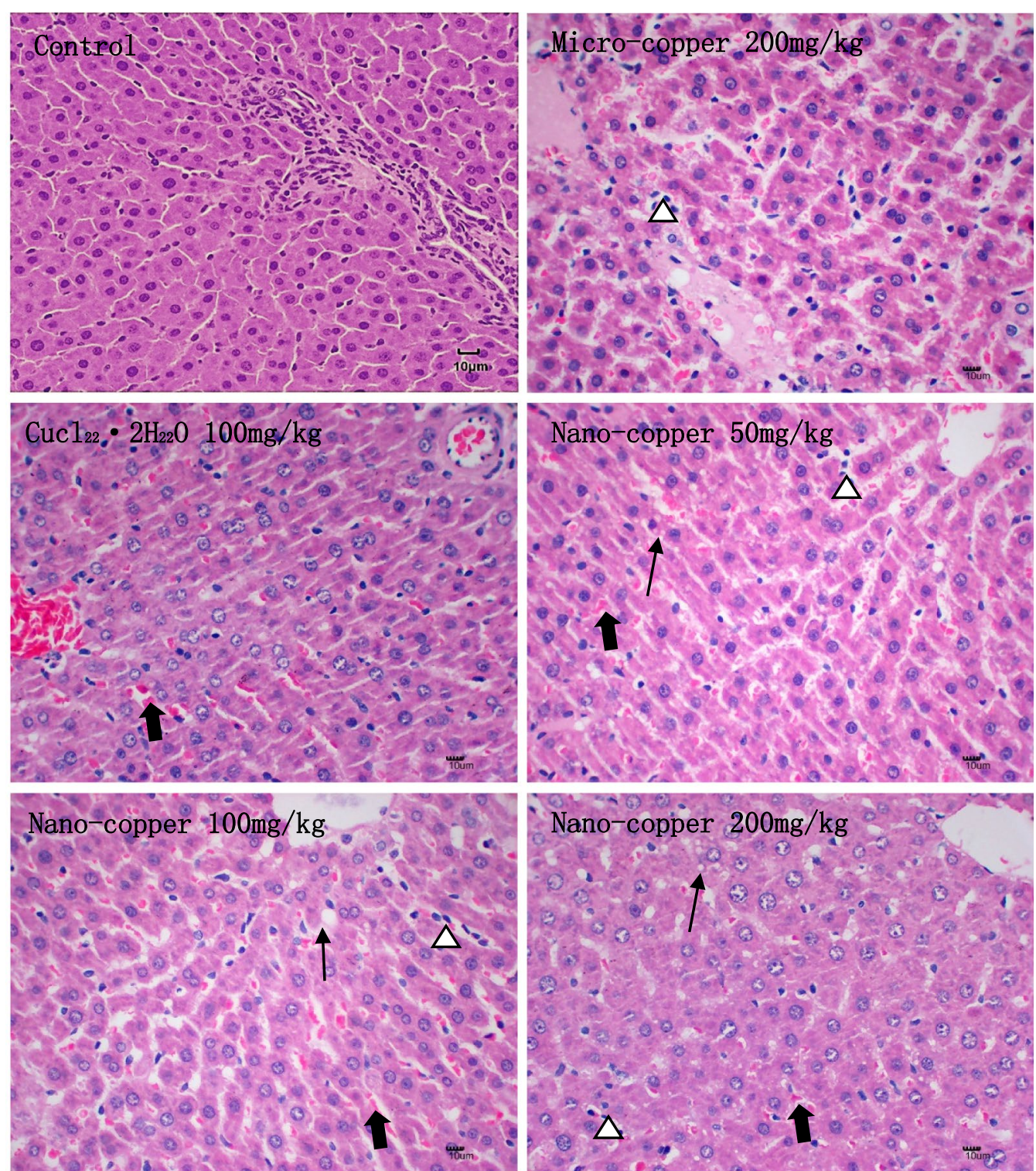

Fig. 3 Histopathological finding in rats treated with various copper preparations. Small vacuoles of hepatocytes (rightwards arrow), inflammation cells infiltration (white up-pointing triangle), sinusoidal congestion (black rightwards arrow)

changes were dose-dependent in nano-copper-treated rats.

\section{Cytokine analysis}

Nano-copper induced the massive release of cytokines (Fig. 4). The levels of IL-1 $\beta$, IL-2, TNF- $\alpha$, MIP-1, and MCP-1 increased significantly in $200 \mathrm{mg} / \mathrm{kg}$ nano-copper-treated rats. The amount of IL-6 increased significantly in $\mathrm{Cu}$ ions and $200 \mathrm{mg} / \mathrm{kg}$ nano-copper-treated rats. The level of IFN- $\gamma$ decreased significantly in the $100 \mathrm{mg} / \mathrm{kg}$ nano-copper-treated rats, while it increased significantly in the $1 \mu \mathrm{m}$ micro-copper and $200 \mathrm{mg} /$ $\mathrm{kg}$ nano-copper-treated groups. The concentrations of $\mathrm{COX}-2$ decreased in $1 \mu \mathrm{m}$ copper and $\mathrm{Cu}$ ions-groups rats but induced in rats treated with $200 \mathrm{mg} / \mathrm{kg}$ nanocopper. Only high dose of nano-copper caused significant increasing of different inflammation cytokines, which were different from the impacts of micro-copper and $\mathrm{Cu}$ ions.

\section{Oxidative stress analysis}

Only nano-copper caused the oxidative stress in the liver of rats. The concentration of liver MDA increased in $200 \mathrm{mg} / \mathrm{kg}$ nano-copper-treated rats. The level of NO 

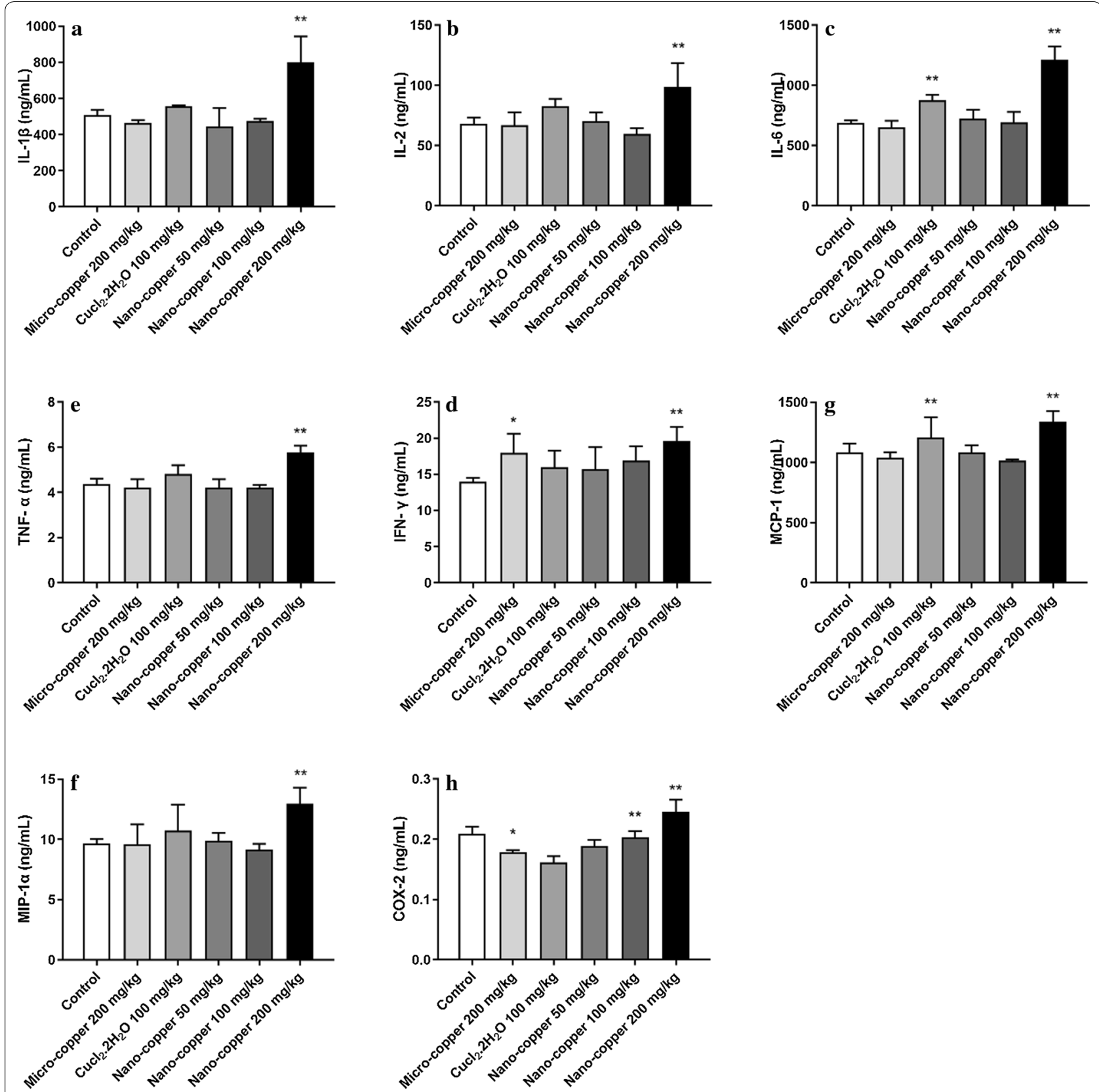

Fig. 4 Cytokine content of livers of the various groups of rats. IL-1 $\beta$, IL-2, IL-6, IFN- $\gamma$, TNF-a, MIP-1, MCP-1, and COX-2. ${ }^{*} p<0.05$; ${ }^{* *} p<0.01$

and iNOS increased significantly in a dose-dependent manner in nano-copper-treated rats. Similarly, the concentrations of CAT decreased in $50 \mathrm{mg} / \mathrm{kg}$ nano-copper-treated rats but increased significantly in $200 \mathrm{mg} /$ $\mathrm{kg}$ nano-copper-treated rats. Nano-copper caused dose-dependent increase of oxidative stress in liver, but there were no changes on the expression of SOD and GSH-Px (Fig. 5).
mRNA expression of nuclear receptors and CYP enzymes

The different sources and dose of copper have different impact on the expression of CYP genes and receptors, but high dose of nano-copper shown strong inhibition effect on it. The level of CYP450 1A2 increased in $1 \mu \mathrm{m}$ copper-treated rats, but it inhibited significantly by $\mathrm{Cu}$ ions and $100 \mathrm{mg} / \mathrm{kg}$ or $200 \mathrm{mg} / \mathrm{kg}$ of nano-copper (Fig. 6a). The level of CYP450 2C11 (Fig. 6b) significantly 

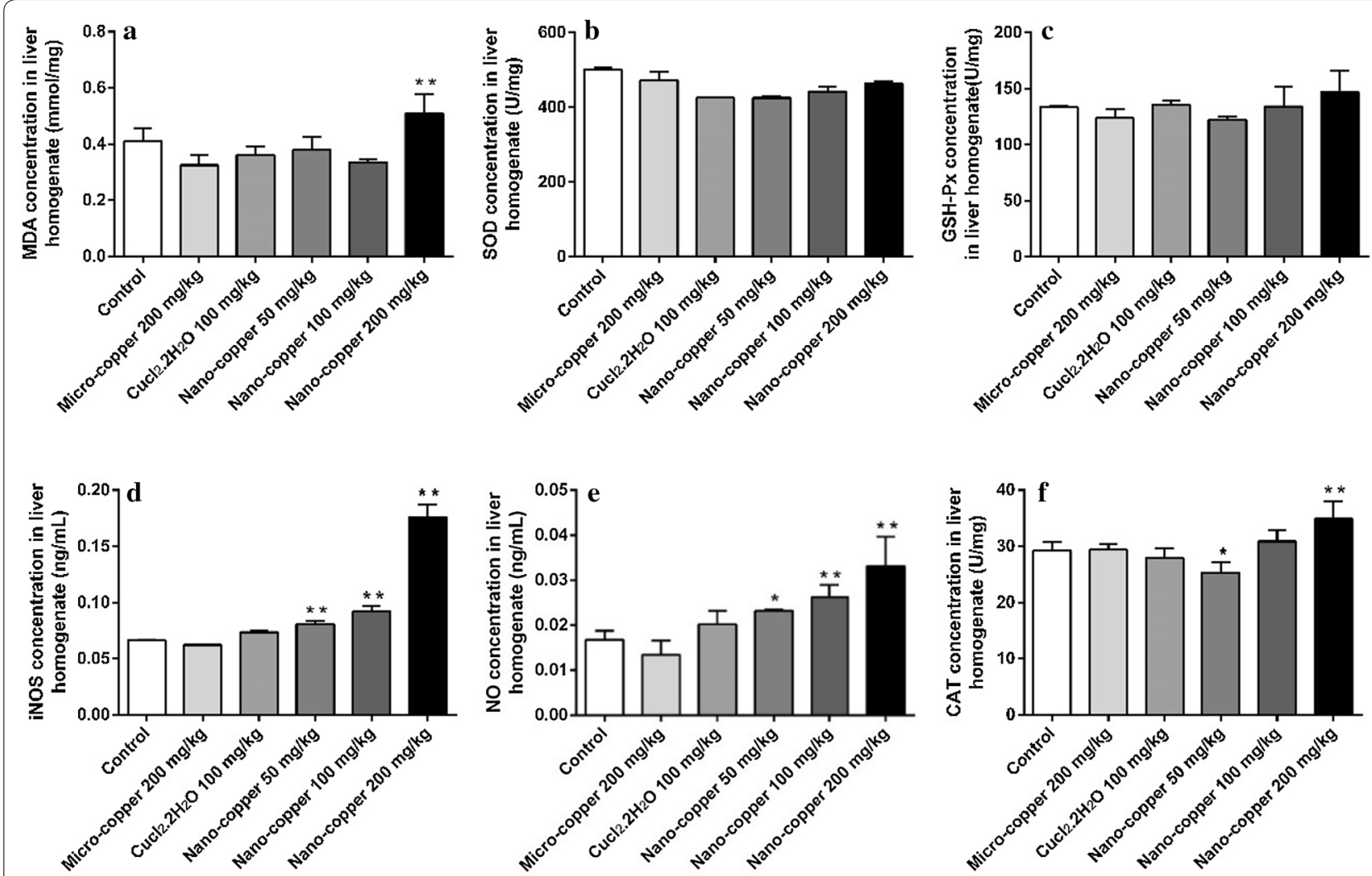

Fig. 5 The levels of oxidative stress markers in rat livers. a MDA, malondialdehyde; $\mathbf{b}$ SOD, superoxide dismutase; c GSH-Px, glutathione peroxidase; d NO, nitric oxide; e iNOS, inducible nitric oxide synthase; fCAT, catalase. ${ }^{*} p<0.05 ;{ }^{* *} p<0.01$

increased by $50 \mathrm{mg} / \mathrm{kg}$ and $100 \mathrm{mg} / \mathrm{kg}$ nano-copper, but it decreased with $200 \mathrm{mg} / \mathrm{kg}$ nano-copper. The level of CYP450 2D6 (Fig. 6c) decreased significantly with $100 \mathrm{mg} / \mathrm{kg}$ and $200 \mathrm{mg} / \mathrm{kg}$ nano-copper. The level of CYP450 2E1 (Fig. 6d) significantly increased with $1 \mu \mathrm{m}$ $\mathrm{Cu}$ ions and $50 \mathrm{mg} / \mathrm{kg}$ nano-copper. The level of CYP450 $3 A 1$ (Fig. 6e) significantly decreased by $1 \mu \mathrm{m}, 100$, and $200 \mathrm{mg} / \mathrm{kg}$ nano-copper. The levels of PXR (Fig. 6f) and $C A R$ (Fig. 6g) decreased in a dose-dependent manner by nano-copper, but the level of $C A R$ increased by $\mathrm{Cu}$ ions. The level of rats $A H R$ (Fig. 6h) decreased in a dosedependent manner by nano-copper and decreased by $1 \mu \mathrm{m}$ micro-copper and $\mathrm{Cu}$ ions.

\section{Protein expression of nuclear receptors and CYP enzymes}

The protein expression changes consistent with the changes of mRNA (Figs. 7 and 8), the inhibition mainly caused by 100 and $200 \mathrm{mg} / \mathrm{kg}$ nano-copper. The relative protein level of CYP450 1A2 increased significantly in rats treated with $1 \mu \mathrm{m}$ copper, but decreased significantly in $100 \mathrm{mg} / \mathrm{kg}$ and $200 \mathrm{mg} / \mathrm{kg}$ nano-copper-treated rats. The level of CYP450 2C11 significantly increased with
$\mathrm{Cu}$ ions, 50 and $100 \mathrm{mg} / \mathrm{kg}$ nano-copper, but significantly decreased in $200 \mathrm{mg} / \mathrm{kg}$ nano-coper. The level of CYP450 2D6 decreased significantly with 100 and $200 \mathrm{mg} / \mathrm{kg}$ nano-copper. The level of CYP450 2E1 increased significantly in $1 \mu \mathrm{m}$ copper, $\mathrm{Cu}$ ions, 50 and $100 \mathrm{mg} / \mathrm{kg}$ nanocopper-treated rats. The level of CYP450 3A1 decreased significantly in rats treated with $1 \mu \mathrm{m}$ copper, and decreased in a dose-dependent manner in nano-coppertreated rats. High dose of nano-copper strongly inhibited the expression of nuclear receptors, which were different to the impact of micro-copper and $\mathrm{Cu}$ ions.

\section{CYP450 enzyme activities}

Decrease in enzymatic activity was accompanied by the reduced genes and proteins expression (Fig. 9). CYP450 $1 \mathrm{~A} 2$ activity decreased significantly in rats treated with $\mathrm{Cu}$ ions, $100 \mathrm{mg} / \mathrm{kg}$, and $200 \mathrm{mg} / \mathrm{kg}$ nano-copper. The activity of CYP450 2C11 decreased significantly in rats treated with $200 \mathrm{mg} / \mathrm{kg}$ nano-copper. The activities of CYP450 2D6 and CYP450 2E1 decreased in $100 \mathrm{mg} / \mathrm{kg}$ and $200 \mathrm{mg} / \mathrm{kg}$ nano-copper-treated rats. CYP450 3A1 decreased significantly in rats treated with $200 \mathrm{mg} / \mathrm{kg}$ 

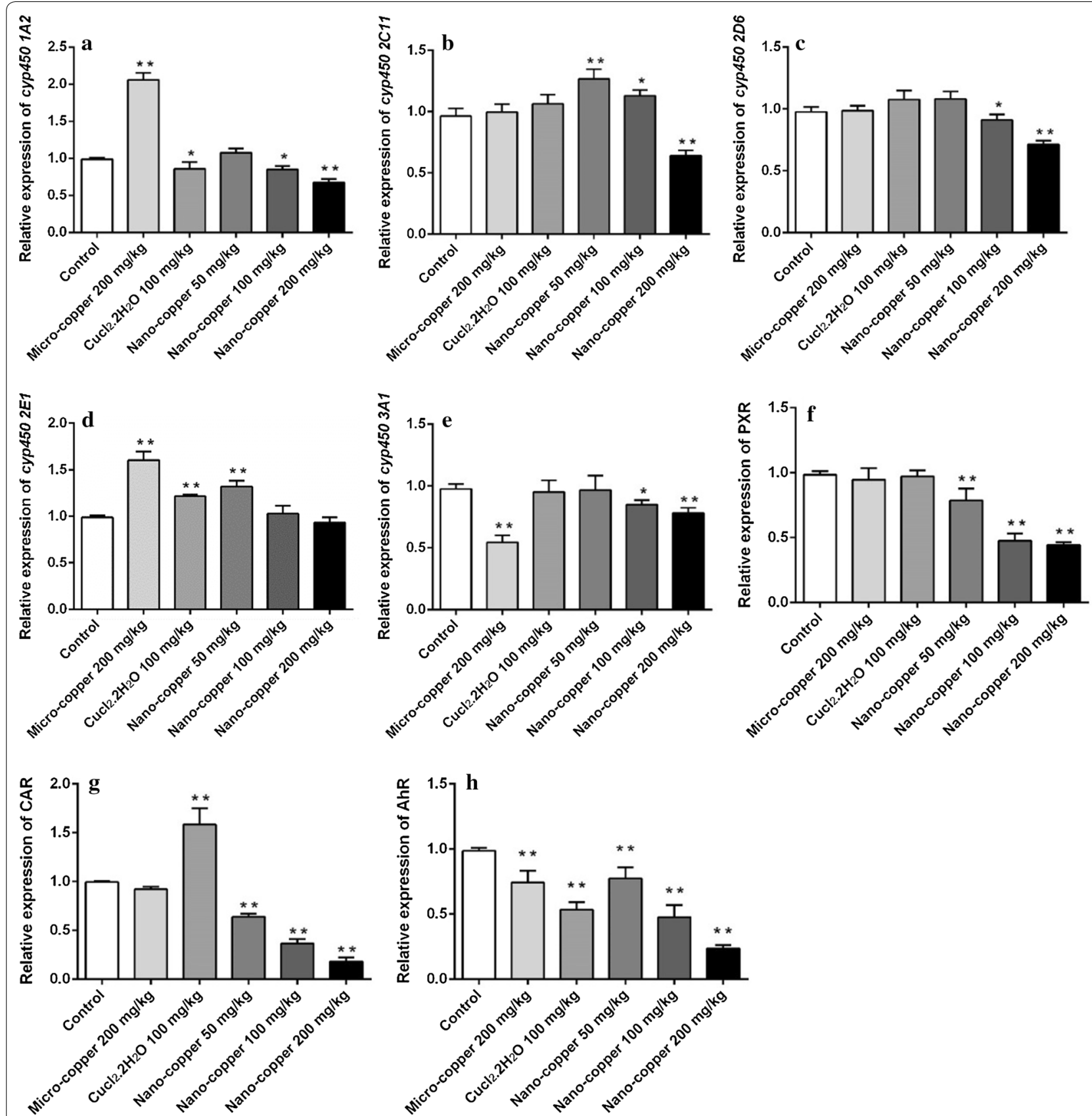

Fig. 6 mRNA expression of CYP450 and nuclear receptor. CYP450 1A2 (a), 2C11 (b), 2D6 (c), 2E1 (d), 3A1 (e), PXR (f), CAR (g) and AHR (h). * $p<0.05$; ${ }^{* *} p<0.01$

nano-copper. Only high concentration of nano-copper inhibited all of the enzymes, and micro-copper and $\mathrm{Cu}$ ions did not have impacted the enzyme activities in liver.

\section{Signaling pathway analysis}

NF- $\mathrm{kB}$, STAT, and MAPK were the main pathways activated by nano-copper during the process of treatment (Fig. 10). The level of NF-kB was induced by 100 and
$200 \mathrm{mg} / \mathrm{kg}$ nano-copper, but $\mathrm{p}-\mathrm{NF}-\mathrm{kB}$ just increased significantly in $200 \mathrm{mg} / \mathrm{kg}$ nano-copper-treated rats. The total and phosphorylated levels of JNK, p38 and ERK $1 / 2$ were induced in 100 and $200 \mathrm{mg} / \mathrm{kg}$ nanocopper-treated rats. The signal pathway of STAT5 also activated by nano-copper, but the level of STAT3 just increased in total protein. The signals of Akt, p70S6K, CERB did not change during the process of treatment. 

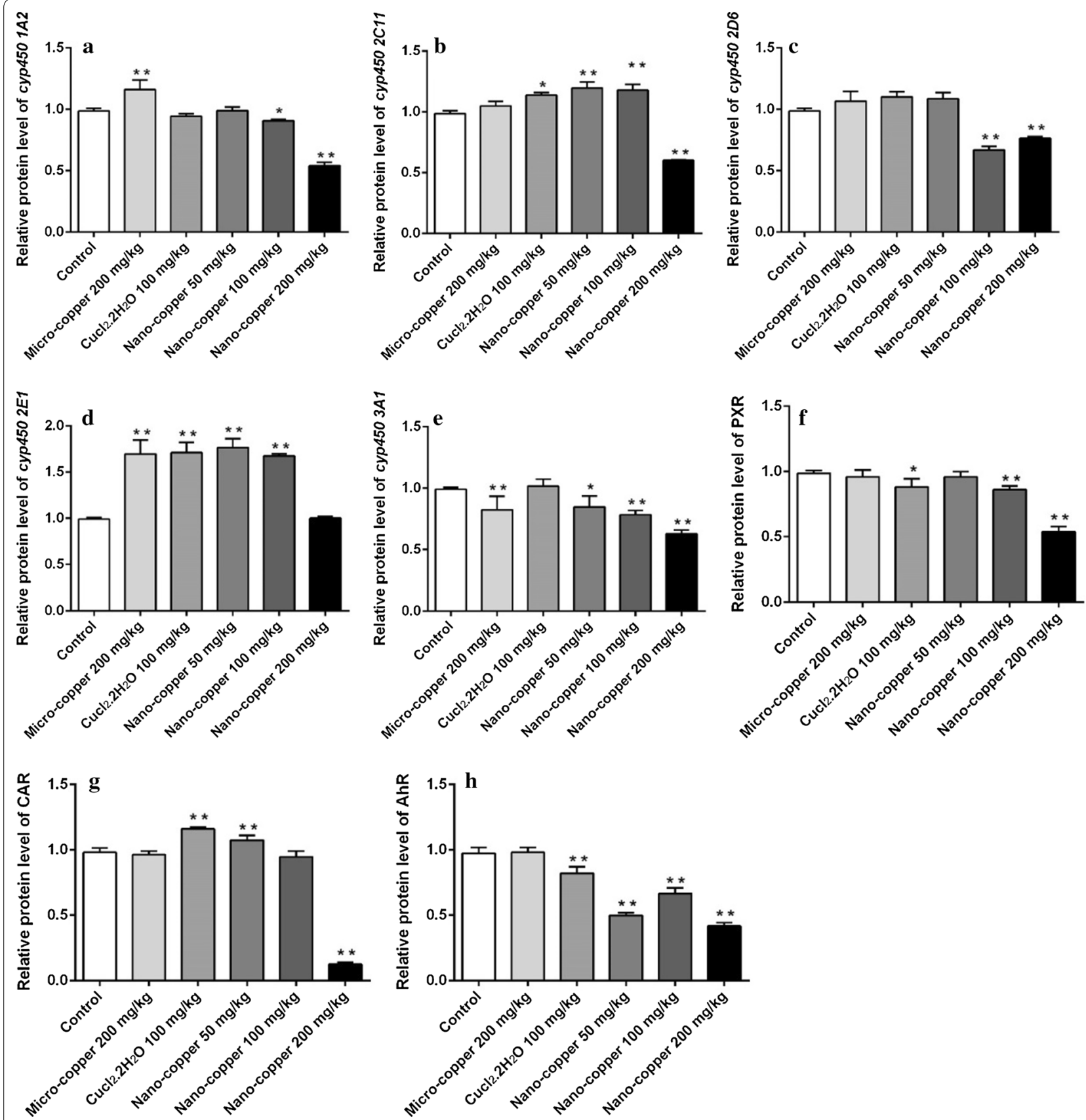

Fig. 7 Protein expression of nuclear receptors and CYP enzymes. Quantification of the protein bands as determined with ImageJ. ${ }^{*} p<0.05$; ${ }^{* *} p<0.01$

\section{Discussion}

The high dose of nano-copper caused obvious liver damage in rat, because the level of AST and ALP were increased significantly, which are used as common indicators of liver injury [34]. Liver is the main organ for protein synthesis; the contents of ALB, GLB, and TP decreased significantly after nano-copper causing liver dysfunction. Direct proof of liver damage was shown in the histopathological results, due to the dosedependent degree of hepatocyte degeneration [35]. The increased CREA also indicated that kidney injury was caused by nano-copper [36].

Nano-copper can break different biological barriers and enter the body's circulation [37-39], then accumulate 


\begin{tabular}{|c|c|}
\hline CYP1A2 & 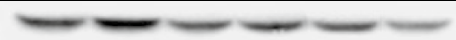 \\
\hline CYP $2 C 11$ & 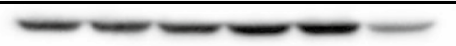 \\
\hline CYP 2D6 & 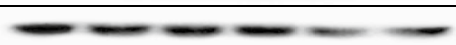 \\
\hline CYP 2E1 & $--\omega-\cdots$ \\
\hline CYP $3 A 1$ & we $=0$ \\
\hline AHR & 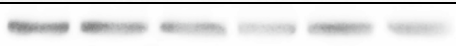 \\
\hline CAR & $-\cdots-\cdots$ \\
\hline$P X R$ & 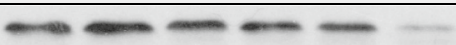 \\
\hline \multirow[t]{2}{*}{$\beta$-Actin } & 00 \\
\hline & $\begin{array}{llllll}\mathrm{A} & \mathrm{B} & \mathrm{C} & \mathrm{D} & \mathrm{E} & \mathrm{F} \\
\end{array}$ \\
\hline
\end{tabular}

Fig. 8 Western blot analysis displays dose-dependent inhibition of nano-copper in liver CYP enzymes. A: Control, B: Micro-copper, C: $\mathrm{CuCl}_{2} \cdot 2 \mathrm{H}_{2} \mathrm{O}$, D: Nano-copper $50 \mathrm{mg} / \mathrm{kg}$, E: Nano-copper $100 \mathrm{mg} / \mathrm{kg}$, F: Nano-copper 200 mg/kg

in liver, and interact with biomacromolecules. Oxidative stress is the main cause of organ cytotoxicity caused by nano-copper [40]. Oxidative stress is also related to inflammation with the release of many inflammatory cytokines [41-43]. The levels of the inflammatory cytokines IL-1 $\beta$, TNF- $\alpha$, IL-6, and MIP-1 increased significantly, especially at the highest doses of the nanocopper-treated rats. Also, the markers of oxidative stress (MDA, NO, iNOS, and CAT) increased significantly. We found that $\mathrm{Cu}$ ions also caused inflammation in the rat liver, so we speculate that the liver inflammation and oxidative stress were caused by nano-copper and $\mathrm{Cu}$ ions together when part of the nano-copper was ionized in stomach acid [44, 45]. Oxidative stress and inflammatory response caused by nano-copper will further aggravate liver dysfunction [46].

The CYP450 subfamily plays an important role in the metabolism of most kinds of drugs [47]. Oxidative stress and inflammation are important factors that affect the expression of CYP450 in the liver [48-51]. Many phaseI enzymes are also regulated by specifically transcription factors, such as the AhR, CAR, and PXR [52, 53]. In this work, mRNA expression and protein expression of PXR, CAR, and AHR were significantly suppressed by nanocopper administration. According to reported studies $[52,54]$, decreased PXR mainly affects the expression of CYP450 2C and 3A subtypes, while decreased CAR and AHR mainly affect the expression of CYP450 1A subtype. In this study, the mRNA, protein, and activity of CYP450 $1 \mathrm{~A} 2$ and 2D6 decreased significantly in medium and high
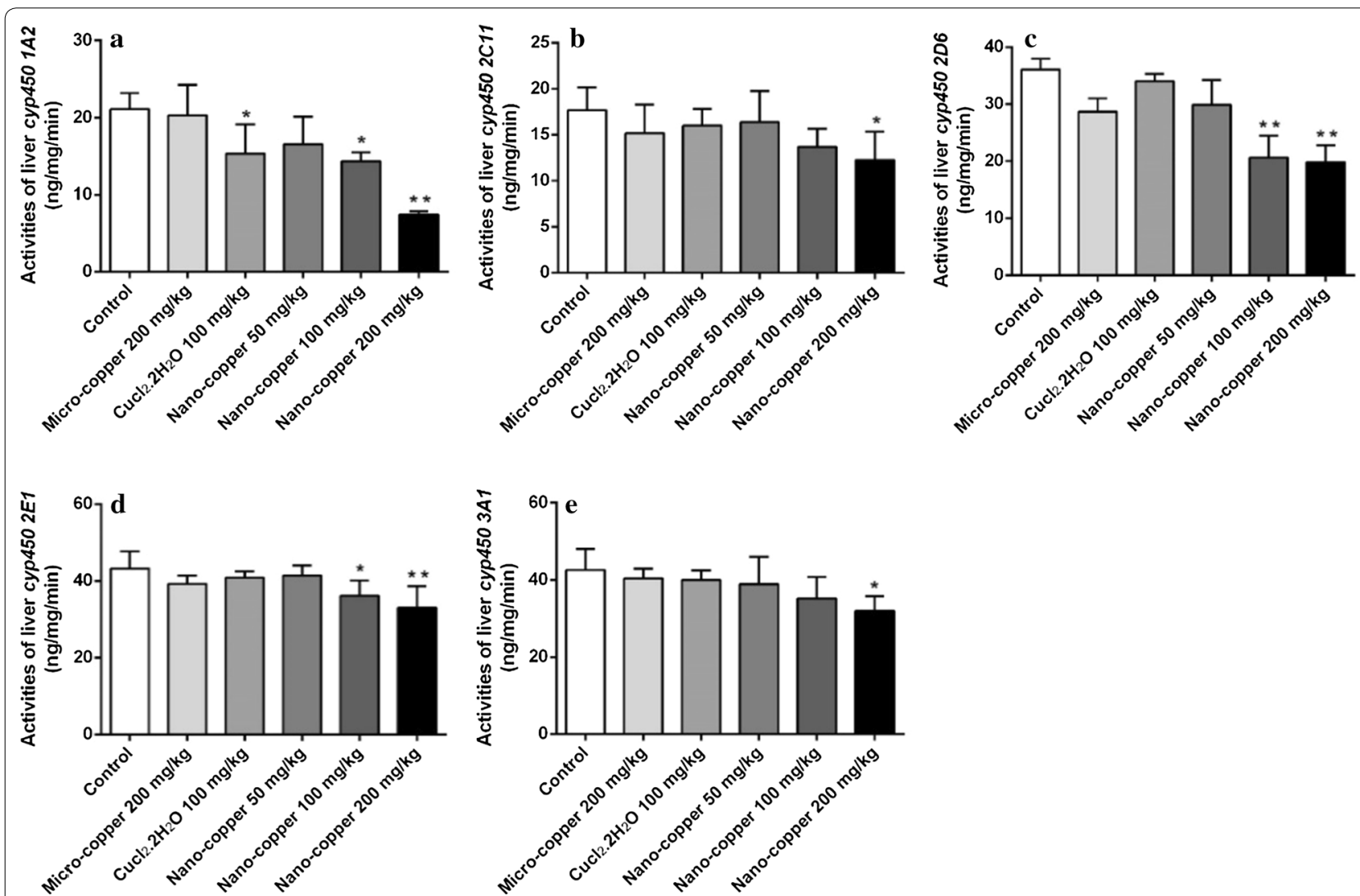

Fig. 9 Activities of CYP450 enzymes in rats. CYP450 1A2 (a), 2C11 (b), 2D6 (c), 2E1 (d), 3A1 (e). ${ }^{*} p<0.05 ;{ }^{* *} p<0.01$ 


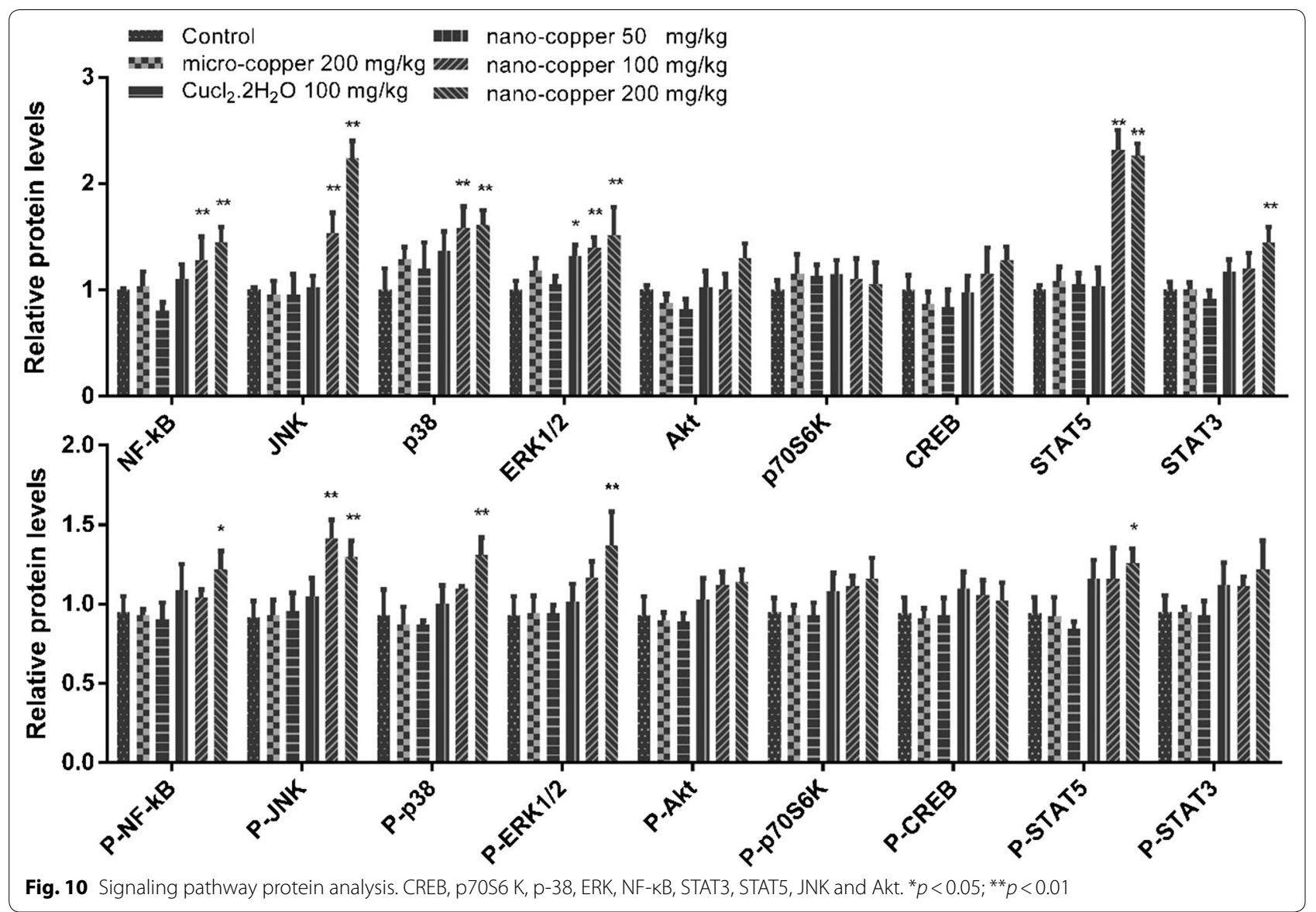

doses of nano-copper; the mRNA and protein expression of CYP450 3A1 decreased significantly, but the activity only decreased in the $200 \mathrm{mg} / \mathrm{kg}$ dose. CYP450 2C11 and $2 \mathrm{E} 1$ were induced by low-dose but inhibited by high dose of nano-copper, which may be due to the increased levels of TNF- $\alpha$ and IL- 6 [55].

The regulation of CYP450 s also related to key transcription and protein kinases, such as NF-kB and MAPKs $[56,57]$. The signaling pathways also cross-talk with oxidative, inflammatory, and nuclear receptors to affect the expression of CYP450 enzymes [58]. In our results, nanocopper mainly affected NF-kB, MAPK, and STAT5, which significantly increased the phosphorylated proteins and the ratio of phosphorylated and total protein. The level of $\mathrm{p}-38$, JNK, and ERK increased significantly, which was found to function upstream of the I $\kappa B-\alpha / N F-\kappa B$ signaling pathway [58]. NF- $\mathrm{kB}$ is an important transcription factor that regulates the expression of CYP450 [59]. The JAK/STAT signaling pathway is involved in the expression of various cytokines $[60,61]$, which indirectly regulates the expression of CYP450 enzymes. The regulation of CYP450 is a complex process, and the effects of nanocopper on CYP450 enzyme involve the activation of several regulatory signaling pathways, the mechanism of which deserves further study.

\section{Conclusions}

Our study has indicated that sub-chronic exposure to nano-copper caused obvious liver injury and decreased the expression and activity of drug metabolism enzymes in rats. These changes are accompanied by the appearance of oxidative stress, inflammatory reactions, and key regulation pathways activated in the liver of rats. To date, most of the literature only focused on the regular toxicity of nano-copper; our research focused on the potential risks of nano-copper-drug interactions, but more studies are still needed to explain the detail mechanism.

\section{Abbreviations}

CYP450: cytochrome P450 enzyme; CAR: constitutive receptor; PXR: pregnane $X$ receptor; PPAR: peroxisome proliferator activated receptor; IL: interleukin: CAR: constitutive androstane receptor; AHR: aryl hydrocarbon receptor; TNF-a: tumor necrosis factor-alpha; MCP-1: monocyte chemotactic protein-1; (MIP)-1 a: macrophage inflammatory protein-1 a; ALT: alanine aminotransferase; AST: aspartate aminotransferase; ALP: alkaline phosphatase; A/G: albumin/ globulin; CK: creatine kinase; GLB: globulin; TP: total protein; CREA: creatinine; TG: triglyceride; ALB: albumin; TC: cholesterol. 


\section{Acknowledgements}

The authors thank Bo Jing for technical assistance and help in the lab, and Ms. Salazar Monique S for kind help to edit the language for us.

\section{Authors' contributions}

$H T, M X$ and $J$ are the co-first authors, they performed the exposure experiment, the histological examination of the liver, the biochemical analyses and the statistical analyses. JL and LZ supervised the histological examinations and designed the study. GY supervised the biochemical analyses. FS did the data analysis. $\mathrm{Cl}, \mathrm{HC}$ and $\mathrm{YW}$ performed the activity analyses. $\mathrm{YL}$ supervised all the analyses. All authors read and approved the final manuscript.

\section{Funding}

This work was supported by the Guizhou Provincial Science and Technology Fund Project, China (No: J[2019]1313).

\section{Availability of data and materials}

The datasets used and/or analyzed during the current study are available from the corresponding author on reasonable request.

\section{Ethics approval and consent to participate}

The experiments were conducted in strict accordance with Guiding Principles for the Experimental Animal Ethics Committee and were approved by the Animal Ethical Committee of Sichuan Agricultural University (\#:20171120).

\section{Consent for publication}

Not applicable.

\section{Competing interests}

The authors declare that they have no competing interests.

Received: 6 February 2019 Accepted: 8 May 2019

Published online: 20 May 2019

\section{References}

1. Walther B, Tedin K, Lübke-Becker A (2017) Multidrug-resistant opportunistic pathogens challenging veterinary infection control. Vet Microbiol 200:71-78. https://doi.org/10.1016/j.vetmic.2016.05.017

2. Carmo LP, Schüpbach-Regula G, Müntener C, Chevance A, Moulin G, Magouras I (2017) Approaches for quantifying antimicrobial consumption per animal species based on national sales data: a Swiss example, 2006 to 2013. Eurosurveillance. https://doi.org/10.2807/1560-7917. ES.2017.22.6.30458

3. Liu Y-Y, Wang Y, Walsh TR, Yi L-X, Zhang R, Spencer J, Doi Y, Tian G, Dong B, Huang $X$ (2016) Emergence of plasmid-mediated colistin resistance mechanism MCR-1 in animals and human beings in China: a microbiological and molecular biological study. Lancet Infect Dis 16:161-168. https://doi.org/10.1016/S1473-3099(15)00424-7

4. Swain PS, Rao SB, Rajendran D, Dominic G, Selvaraju S (2016) Nano zinc, an alternative to conventional zinc as animal feed supplement: a review. Anim Nutr 2:134-141. https://doi.org/10.1016/j.aninu.2016.06.003

5. Gangadoo S, Stanley D, Hughes RJ, Moore RJ, Chapman J (2016) Nanoparticles in feed: progress and prospects in poultry research. Trends Food Sci Technol 58:115-126. https://doi.org/10.1016/j.tifs.2016.10.013

6. Chang Z, Zhang H, Dong H, Mehmood K, ljaz M, Ahmad H, Naeem M, Wu Q, Nabi F, Zhu H (2018) Effect of CuSO4 and nano copper on serum antioxidant capacity in Weaned piglets. J Biol Regul Homeost Agents 32:219-224

7. Chang Z, Zhang H, Mehmood K, Luo M, Zhao Y, Nabi WuX, Tian X, Liu $X$, Zhou D (2018) Effect of nano copper on visceral organs and the contents of trace elements in weanling pigs. Toxin Rev. https://doi. org/10.1080/15569543.2017.1421559

8. Uauy R, Olivares M, Gonzalez M (1998) Essentiality of copper in humans. Am J Clin Nutr 67:952S-959S. https://doi.org/10.1093/ajcn/67.5.952S

9. Borkow G, Gabbay J (2005) Copper as a biocidal tool. Curr Med Chem 12:2163-2175. https://doi.org/10.2174/0929867054637617

10. Villanueva ME, Diez AMadR, González JA, Pérez CJ, Orrego M, Piehl L, Teves S, Copello GJ (2016) Antimicrobial activity of starch hydrogel incorporated with copper nanoparticles. ACS Appl Mater Interfaces 8:16280-16288. https://doi.org/10.1021/acsami.6b02955

11. Azizi M, Ghourchian H, Yazdian F, Dashtestani F, AlizadehZeinabad H (2017) Cytotoxic effect of albumin coated copper nanoparticle on human breast cancer cells of MDA-MB 231. PLoS ONE 12:e0188639. https://doi. org/10.1371/journal.pone.0188639

12. Mroczek-Sosnowska N, Łukasiewicz M, Wnuk A, Sawosz E, Niemiec J, Skot A, Jaworski S, Chwalibog A (2016) In ovo administration of copper nanoparticles and copper sulfate positively influences chicken performance. J Sci Food Agric 96:3058-3062. https://doi.org/10.1002/jsfa.7477

13. Tang H, Xu M, Zhou X, Zhang Y, Zhao L, Ye G, Shi F, Lv C, Li Y (2018) Acute toxicity and biodistribution of different sized copper nano-particles in rats after oral administration. Mater Sci Eng C 93:649-663. https://doi. org/10.1016/j.msec.2018.08.032

14. Lee I-C, Ko J-W, Park S-H, Shin N-R, Shin I-S, Moon C, Kim J-H, Kim H-C, Kim J-C (2016) Comparative toxicity and biodistribution assessments in rats following subchronic oral exposure to copper nanoparticles and microparticles. Particle Fibre Toxicol 13:56. https://doi.org/10.1186/s1298 9-016-0169-X

15. Braakhuis HM, Gosens I, Krystek P, Boere JA, Cassee FR, Fokkens PH, Post JA, Van Loveren H, Park MV (2014) Particle size dependent deposition and pulmonary inflammation after short-term inhalation of silver nanoparticles. Particle Fibre Toxicol 11:49. https://doi.org/10.1186/s1298 9-014-0049-1

16. Zhang H, Chang Z, Mehmood K, Abbas RZ, Nabi F, Rehman MU, Wu X, Tian X, Yuan X, Li Z (2018) Nano copper induces apoptosis in PK-15 cells via a mitochondria-mediated pathway. Biol Trace Elem Res 181:62-70. https://doi.org/10.1007/s12011-017-1024-0

17. Cholewińska E, Ognik K, Fotschki B, Zduńczyk Z, Juśkiewicz J (2018) Comparison of the effect of dietary copper nanoparticles and one copper (II) salt on the copper biodistribution and gastrointestinal and hepatic morphology and function in a rat model. PLOS ONE 13:e0197083. https:// doi.org/10.1371/journal.pone.0197083

18. Shi M, Kwon HS, Peng Z, Elder A, Yang H (2012) Effects of surface chemistry on the generation of reactive oxygen species by copper nanoparticles. ACS Nano 6:2157-2164. https://doi.org/10.1021/nn300445d

19. Worthington $\mathrm{KL}$, Adamcakova-Dodd A, Wongrakpanich A, Mudunkotuwa IA, Mapuskar KA, Joshi VB, Guymon CA, Spitz DR, Grassian VH, Thorne PS (2013) Chitosan coating of copper nanoparticles reduces in vitro toxicity and increases inflammation in the lung. Nanotechnology 24:395101. https://doi.org/10.1088/0957-4484/24/39/395101

20. Poloyac SM (2017) Drug and fatty acid cytochrome P450 metabolism in critical care. In: Drug metabolism in diseases. Academic Press, Boston, pp 115-138. https://doi.org/10.1016/B978-0-12-802949-7.00005-5

21. Wang J, Rahman MF, Duhart HM, Newport GD, Patterson TA, Murdock RC, Hussain SM, Schlager JJ, Ali SF (2009) Expression changes of dopaminergic system-related genes in PC12 cells induced by manganese, silver, or copper nanoparticles. Neurotoxicology 30:926-933. https://doi. org/10.1016/j.neuro.2009.09.005

22. Ekhart C, Matic M, Kant A, van Puijenbroek E, Schaik RV (2017) CYP450 genotype and aggressive behavior on selective serotonin reuptake inhibitors. Pharmacogenomics 18:613-620. https://doi.org/10.2217/ pgs-2017-0197

23. Baer-Dubowska W, Szaefer H (2013) Modulation of carcinogen-metabolizing cytochromes P450 by phytochemicals in humans. Expert Opin Drug Metab Toxicol 9:927-941. https://doi.org/10.1517/17425255.2013.795219

24. Morgan ET (2017) Regulation of drug-metabolizing enzymes and drug metabolism by inflammatory responses. In: Drug metabolism in diseases. Academic Press, Boston, pp 21-58. https://doi.org/10.1016/B978-0-12802949-7.00002-X

25. Goossens J, De Bock L, Osselaere A, Verbrugghe E, Devreese M, Boussery K, Van Bocxlaer J, De Backer P, Croubels S (2013) The mycotoxin T-2 inhibits hepatic cytochrome P4503A activity in pigs. Food Chem Toxicol 57:54-56. https://doi.org/10.1016/j.fct.2013.03.009

26. Xu S, Wu Q, Zhang B, Li H, Xu Y, Du Y, Wei L, Liu J (2016) Comparison of mercury sulfides with mercury chloride and methylmercury on hepatic P450, phase-2 and transporter gene expression in mice. J Trace Elem Med Biol 37:37-43. https://doi.org/10.1016/j.jtemb.2016.06.006

27. Daniel W, Haduch A, Syrek M, Boksa J (2006) Direct and indirect interactions between antidepressant drugs and CYP2C6 in the rat liver during 
long-term treatment. Eur Neuropsychopharmacol 16:580-587. https:// doi.org/10.1016/j.euroneuro.2006.01.004

28. Haduch A, Wójcikowski J, Daniel W (2006) The effect of tricyclic antidepressants, selective serotonin reuptake inhibitors (SSRIs) and newer antidepressant drugs on the activity and level of rat CYP3A. Eur Neuropsychopharmacol 16:178-186. https://doi.org/10.1016/j.euron euro.2005.08.004

29. Zhu W-J, Zhang Z-W, Wang X-S, Xu S-W, Li M, Li S (2014) Effects of avermectin on microsomal cytochrome P450 enzymes in the liver and kidneys of pigeons. Environ Toxicol Pharmacol 38:562-569. https://doi. org/10.1016/j.etap.2014.08.011

30. Peng $Y$, Wu H, Zhang $X$, Zhang F, Qi H, Zhong $Y$, Wang $Y$, Sang H, Wang G, Sun J (2015) A comprehensive assay for nine major cytochrome P450 enzymes activities with 16 probe reactions on human liver microsomes by a single LC/MS/MS run to support reliable in vitro inhibitory drug-drug interaction evaluation. Xenobiotica 45:961-977. https://doi. org/10.3109/00498254.2015.1036954

31. Rao MN, Biju B, Ansar A, Mujeeb S, Ramesh M, Srinivas N (2003) 'Open access' generic method for continuous determination of major human CYP450 probe substrates/metabolites and its application in drug metabolism studies. Xenobiotica 33:1233-1245. https://doi.org/10.1080/00498 250310001636877

32. Meyer U, Nyffeler M, Engler A, Urwyler A, Schedlowski M, Knuesel I, Yee BK, Feldon J (2006) The time of prenatal immune challenge determines the specificity of inflammation-mediated brain and behavioral pathology. J Neurosci 26:4752-4762. https://doi.org/10.1523/JNEUR OSCI.0099-06.2006

33. Chantratita N, Tandhavanant S, Myers ND, Seal S, Arayawichanont A, Kliangsa-ad A, Hittle LE, Ernst RK, Emond MJ, Wurfel MM (2013) Survey of innate immune responses to Burkholderia pseudomallei in human blood identifies a central role for lipopolysaccharide. PLOS ONE 8:e81617. https ://doi.org/10.1371/journal.pone.0081617

34. Manna P, Ghosh M, Ghosh J, Das J, Sil PC (2012) Contribution of nanocopper particles to in vivo liver dysfunction and cellular damage: role of IKBa/NF-KB, MAPKs and mitochondrial signal. Nanotoxicology 6:1-21. https://doi.org/10.3109/17435390.2011.552124

35. Chen Z, Meng H, Yuan H, Xing G, Chen C, Zhao F, Wang Y, Zhang C, Zhao $Y$ (2007) Identification of target organs of copper nanoparticles with ICP-MS technique. J Radioanal Nuclear Chem 272:599-603. https://doi. org/10.1007/s10967-007-0631-1

36. Xu M, Tang H, Zhou X, Chen H, Dong Q, Zhang Y, Ye G, Shi F, Lv C, Jing B (2018) Effects and mechanisms of sub-chronic exposure to copper nanoparticles on renal cytochrome P450 enzymes in rats. Environ Toxicol Pharmacol 63:135-146. https://doi.org/10.1016/j.etap.2018.08.004

37. Prabhu BM, Ali SF, Murdock RC, Hussain SM, Srivatsan M (2010) Copper nanoparticles exert size and concentration dependent toxicity on somatosensory neurons of rat. Nanotoxicology 4:150-160. https://doi. org/10.3109/17435390903337693

38. Ingle AP, Duran N, Rai M (2014) Bioactivity, mechanism of action, and cytotoxicity of copper-based nanoparticles: a review. Appl Microbiol Biotechnol 98:1001-1009. https://doi.org/10.1007/s00253-013-5422-8

39. Zhao F, Zhao Y, Liu Y, Chang X, Chen C, Zhao Y (2011) Cellular uptake, intracellular trafficking, and cytotoxicity of nanomaterials. Small 7:13221337. https://doi.org/10.1002/smll.201100001

40. Xu P, Xu J, Liu S, Yang Z (2012) Nano copper induced apoptosis in podocytes via increasing oxidative stress. J Hazard Mater 241:279-286. https:// doi.org/10.1016/j.jhazmat.2012.09.041

41. Manke A, Wang L, Rojanasakul Y (2013) Mechanisms of nanoparticleinduced oxidative stress and toxicity. BioMed Res Int. https://doi. org/10.1155/2013/942916

42. Sarkar A, Das J, Manna P, Sil PC (2011) Nano-copper induces oxidative stress and apoptosis in kidney via both extrinsic and intrinsic pathways. Toxicology 290:208-217. https://doi.org/10.1016/j.tox.2011.09.086

43. Zhang H, WU X, Mehmood K, Chang Z, Li K, Jiang X, Nabi F, ljaz M, Rehman MU, Javed MT (2017) Intestinal epithelial cell injury induced by copper containing nanoparticles in piglets. Environ Toxicol Pharmacol 56:151-156. https://doi.org/10.1016/j.etap.2017.09.010
44. Ruparelia JP, Chatterjee AK, Duttagupta SP, Mukherji S (2008) Strain specificity in antimicrobial activity of silver and copper nanoparticles. Acta Biomater 4:707-716. https://doi.org/10.1016/j.actbio.2007.11.006

45. Lee H-J, Song JY, Kim BS (2013) Biological synthesis of copper nanoparticles using Magnolia kobus leaf extract and their antibacterial activity. J Chem Technol Biotechnol 88:1971-1977. https://doi.org/10.1002/ jctb.4052

46. Gaetke LM, Chow CK (2003) Copper toxicity, oxidative stress, and antioxidant nutrients. Toxicology 189:147-163. https://doi.org/10.1016/50300 $-483 \times(03) 00159-8$

47. Renton KW (2001) Alteration of drug biotransformation and elimination during infection and inflammation. Pharmacol Ther 92:147-163. https:// doi.org/10.1016/S0163-7258(01)00165-6

48. Morgan E (2009) Impact of infectious and inflammatory disease on cytochrome P450-mediated drug metabolism and pharmacokinetics. Clin Pharmacol Ther 85:434-438. https://doi.org/10.1038/clpt.2008.302

49. Robertson G, Leclercq I, Farrell GC (2001) II. Cytochrome P-450 enzymes and oxidative stress. Am J Physiol Gastrointest Liver Physiol 281:G1135G1139. https://doi.org/10.1152/ajpgi.2001.281.5.G1135

50. Aitken AE, Morgan ET (2007) Gene-specific effects of inflammatory cytokines on cytochrome P450 2C, 2B6 and 3A4 mRNA levels in human hepatocytes. Drug Metab Dispos 35:1687-1693. https://doi.org/10.1124/ dmd.107.015511

51. Sunman JA, Hawke RL, LeCluyse EL, Kashuba AD (2004) Kupffer cellmediated IL-2 suppression of CYP3A activity in human hepatocytes. Drug Metab Dispos 32:359-363. https://doi.org/10.1124/dmd.32.3.359

52. Wang Y-M, Ong SS, Chai SC, Chen T (2012) Role of CAR and PXR in xenobiotic sensing and metabolism. Expert Opin Drug Metab Toxicol 8:803-817. https://doi.org/10.1517/17425255.2012.685237

53. Kodama S, Koike C, Negishi M, Yamamoto Y (2004) Nuclear receptors CAR and PXR cross talk with FOXO1 to regulate genes that encode drugmetabolizing and gluconeogenic enzymes. Mol Cell Biol 24:7931-7940. https://doi.org/10.1128/MCB.24.18.7931-7940.2004

54. Aleksunes LM, Klaassen CD (2012) Coordinated regulation of hepatic phase I and II drug-metabolizing genes and transporters using AhR-, CAR-, PXR-, PPARa-, and Nrf2-null mice. Drug Metab Dispos 40:13661379. https://doi.org/10.1124/dmd.112.045112

55. Morgan ET (2001) Regulation of cytochrome p450 by inflammatory mediators: why and how? Drug Metab Dispos 29:207-212

56. Mallick P, Taneja G, Moorthy B, Ghose R (2017) Regulation of drug-metabolizing enzymes in infectious and inflammatory disease: implications for biologics-small molecule drug interactions. Expert Opin Drug Metab Toxicol 13:605-616. https://doi.org/10.1080/17425255.2017.1292251

57. Rushmore TH, Tony Kong A (2002) Pharmacogenomics, regulation and signaling pathways of phase I and II drug metabolizing enzymes. Curr Drug Metab 3:481-490. https://doi.org/10.2174/1389200023337171

58. Gerbal-Chaloin S, lankova I, Maurel P, Daujat-Chavanieu M (2013) Nuclear receptors in the cross-talk of drug metabolism and inflammation. Drug Metab Rev 45:122-144. https://doi.org/10.3109/03602532.2012.756011

59. Li W, Qiu X, Jiang H, Zhi Y, Fu J, Liu J (2015) Ulinastatin inhibits the inflammation of LPS-induced acute lung injury in mice via regulation of AMPK/NF-KB pathway. Int Immunopharmacol 29:560-567. https://doi. org/10.1016/j.intimp.2015.09.028

60. Zordoky BN, El-Kadi AO (2009) Role of NF-KB in the regulation of cytochrome P450 enzymes. Curr Drug Metab 10:164-178. https://doi. org/10.2174/138920009787522151

61. Febvre-James M, Bruyère A, Le Vée M, Fardel O (2018) The JAK1/2 inhibitor ruxolitinib reverses interleukin-6-mediated suppression of drugdetoxifying proteins in cultured human hepatocytes. Drug Metab Dispos 46:131-140. https://doi.org/10.1124/dmd.117.078048

\section{Publisher's Note}

Springer Nature remains neutral with regard to jurisdictional claims in published maps and institutional affiliations. 